CURRENT RESEARCH JOURNAL OF PHILOLOGICAL SCIENCES

(ISSN -2767-3758)

VOLUME 03 ISSUE 01 Pages: 5-8

SJIF IMPACT FACTOR (2021: 5.823 )

OCLC - 1242423883 METADATA IF - 6.925

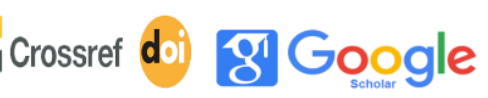

Fon

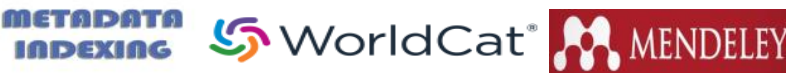

Publisher: Master Journals

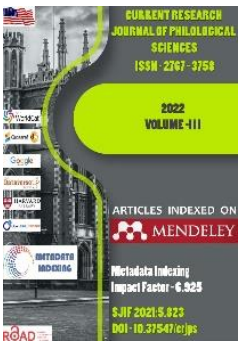

Journal Website: https://masterjournals. com/index.php/crips

Copyright: Original content from this work may be used under the terms of the creative commons attributes 4.0 licence. a

Research Article

\section{A IDENTITY UNDERSTOOD FROM HISTORY}

Submission Date: December 23, 2021, Accepted Date: January 3, 2022, Published Date: January 13, 2022

Crossref doi: https://doi.org/10.37547/philological-crjps-03-01-02

Shokhista S. Akhmedova

Lecturer, Jizzakh State Pedagogical Institute, Jizzakh, Uzbekistan

Zarina O. Muqarova

Student, Jizzakh State Pedagogical Institute, Jizzakh, Uzbekistan

\title{
ABSTRACT
}

This article highlights the uniqueness of Omon Matjon's skill in creating a historical hero. The poet's poem "AlKhwarizmi's journey to the Cave of Ephesus in Byzantium" dedicated to Al- Khwarizmi was analyzed.

\section{KEYWORDS}

History, hero, image, art, originality, skill, lyrics, guise, talent, period.

\section{INTRODUCTION}

Omon Matjon is one of the poets who left his mark on 2oth century Uzbek poetry. His poems and epics have found a worthy place in the treasury of our literature. As a poet, from the very beginning of his poems he showed that he had the most important quality for poetry - originality. O. Matjon, like other poets, sang mainly about the Motherland, about historical figures, about man and his life. Writing a good poem requires 
CURRENT RESEARCH JOURNAL OF PHILOLOGICAL SCIENCES

(ISSN -2767-3758)

VOLUME 03 ISSUE 01 Pages: 5-8

SJIF IMPACT FACTOR (2021: 5. 823)

OCLC - 1242423883 METADATA IF - 6.925

Crossref do

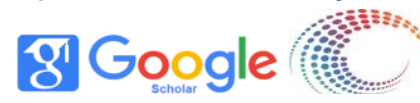
metaparn (5) WorldCat

Publisher: Master Journals

talent, and reading it to the rhythm requires real artistry.

- Omon aka got both of them. This is especially true when reading the poem itself: the edges of the poem shine like crystal as you read the lines piece by piece, the delicate parts gently, and the delicate parts loudly. The charm is bulging and the buttons are shiny, says Safo Alloyar in one of his interviews [1;29].

\section{THE MAIN RESULTS AND FINDINGS}

After all, writing a poem, reading a poem skillfully, and creating the image of a historical hero in a poem require a special talent from the poet. In particular, it is no exaggeration to say that the image of the poet Turabekkhanim, Najmiddin Kubro, Al-Khwarizmi, Hazrat Yassavi, Khoja Ahror Wali and historical figures in the collection "Scream of the Swan" is a hymn to human thought.

In the words of O. Sharafiddinov, the artist's historical legends written in the twentieth century and his skill in creating a lyrical hero, opened the eyes of the leaking source of creativity [2; 54]. After all, in the following poem of the poet...

Xorazmda tog'lar yo'q emas, bor! (There are no mountains in Khorezm!)

Xorazm tog'lari (Khorezm mountains)

vohani tongda quyoshdan to'sib qo'ymaslik uchun... (to keep the oasis from the sun in the morning...)

odamlar qiyofasida yashashadi! (live in the guise of people!)

Xorazmiy, (Khorezmi,)

Beruniy, (Beruniy,)
Shayx Najmiddin Kubro, (Sheikh Najmiddin Kubro,)

Zamaxshariy, (Zamakhshariy,)

Pahlavon Mahmud, (Pakhlavon Mahmud,)

Ogahiy, (Ogakhiy,)

Hojixon, (Hojikhon,)

Komiljon...[3;67] (Komiljon...)

The poet reflected the subtleties of the creation of artistic images of great historical figures in a unique way. Critic Ozod Sharafiddinov describes the historical images in Hakkush's proverbs as follows: Its legends, high spiritual qualities such as solidarity, friendship, justice, conscientiousness, devotion to the country, devotion to the Motherland; reveals vices such as selfishness, unscrupulousness, indifference, betrayal at a high artistic level.

From the above considerations, it is clear that Omon Matjon's books, imbued with a deep humanistic pathos, enrich our literature today, gives new souls to our psyche and takes readers to the world of eternal spiritual masterpieces.

O.Matjon's poem "Al-Khwarizmi's Journey to the Cave of Ephesus in Byzantium" dedicated to Al-Khwarizmi describes the period of the scientist's life and research in the world of science. Khorezm had heard a lot about the mystery of the cave of Ephesus, so he got out of the caravan passing through the Byzantine city and looked for the cave. But a sheikh resists without entering the cave and tries to gather the crowd and kill the scholar.

Shayx! Bu yerga meni tanim qayg'usi emas, (Sheikh! It's not a pain to recognize me here,) 
CURRENT RESEARCH JOURNAL OF PHILOLOGICAL SCIENCES

(ISSN -2767-3758)

VOLUME 03 ISSUE 01 Pages: 5-8

SJIF IMPACT FACTOR (2021: 5. 823)

OCLC - 1242423883 METADATA IF - 6.925

\section{Crossref dof}

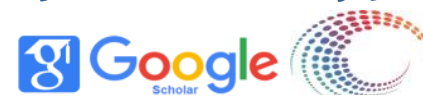

metaphta

5) WorldCat" for MENDELEY

Publisher: Master Journals

Mag'rur ruhim ,umid, imon yetaklab keldi! (My proud spirit, hope, and faith have led!)

To bilayin, “Quron”dagi ta'rif dalilin: (Let me give you an explanation of the definition in the Qur'an:)

Bunda rostdan, "Xudo- yolg'iz" deya ishongan (He really believed in God alone)

Norasida yigitchalar, necha zamonkim, (Homeless guys, how old are you,)

Xuddi Jannat uyqusida tinch yoturmilar?! (Are they sleeping peacefully in Paradise?)

Vujudlari tirik emish, yurak teparmish! (Their bodies are alive, their hearts are beating!)

Axir inson tanasining o'zi to'ymas g'or, (After all, the human body is an insatiable cave,)

Bular esa necha yillar g'orda nihondir! (And they've been in the cave for years!)

Yo'l ber menga![4;158] (Let me in!)

We have known for a long time that the supremacy of religious sciences over secular sciences was clearly shown in the sayings of Sheikh and Khorezmi. The scientist then skillfully enters the cave, where Baghdadi gives the gold to the people, and is amazed to see that some creatures fluttered their wings and flew, and many human bones. Suddenly, from behind, the allanima blossomed, and as it turned, people were closing the mouth of the cave:

Hoy, bu nima qilganlaring! Mana, chiqyapman! (Hey, that's what you did! Here I go!)

Keragi yo'q bu lahmning menga sirayam! (No sense in telling you now - I don't wanna ruin the suprise.)
O'zlaringa buyursin! Shayx, qo'ysinlar! Qaytdim... (Let them do it! Sheikh, let them go! I'm back...)

But ignorant people close the mouth of the cave and plunge it into eternal darkness. Khorezmi, sitting on a rock with a thousand regrets, says:

Endi bildim bunda ko'plar topgan qismatni! (Now I know the fate of many!)

Yurak yutib yo shahd etib kim kirar bo'lsa, (Whoever enters with a heartbeat or a sigh,)

Mana, shunday, orqasidan yo'Ini ko'mishgan! (That's how they buried the road behind them!)

Many of our thinkers have perished in the path of science, and the ignorant have condemned them to the following fate:

Ammo juda xunuk ish bu: chiqa olmasam, (But the worst thing is this: if I can't get out,)

Men ham manovi fidoyi va jannati jonlar ( $\mathrm{I}$ am also a selfless and heavenly soul)

Sirasiga qo'shilaman- o'lik jon! Lekin, (I agree - dead soul! However,)

Uyquda deb o'ylasalar meni ham -yomon! (Too bad they think I'm asleep!)

To us, the mysterious cave is the ocean of knowledge, and human bones are the devotees whose bodies die and whose souls live forever in the way of knowledge. Our ancestors were great people, because it is said that an unjust society nurtures strong people, strong people lay the foundation for building an independent state, and an independent state raises weak people. That is why living in an independent country and not being compatible with our ancestors is sometimes thought-provoking. 
CURRENT RESEARCH JOURNAL OF PHILOLOGICAL SCIENCES

(ISSN -2767-3758)

VOLUME 03 ISSUE 01 Pages: 5-8

SJIF IMPACT FACTOR (2021: 5.823 )

OCLC - 1242423883 METADATA IF - 6.925

When the poet was asked what he focused on in creating historical images, the author replied: I have always been attached to Navoi and Agahi's poems, but I have always been afraid to write about Mashrab. Because he is a saint. To write it, a person must be in a special situation. You can dare to write if you are not chased by a sledgehammer in the afternoon. You can't joke with saints.

\section{CONCLUSION}

There are great people like that. In order to write about them, you must either be seen in a dream or be spiritually prepared. When writing about them, one should go through certain religious mystical rules, purify oneself, and then clap one's hands. This is a great tradition. [5; 457]

In general, the magic of true art is that in it all the universal universal truths are different human characters in new life situations, it is revealed through human destinies, and as a result the old truths seem new to the reader every time, the soul is shaken anew, a new wave of excitement ensues.

\section{REFERENCES}

1. https:www.gazeta.uz.2020/10/29.Y

2. O.Sharafiddinov "Loyalty to the truth". Literary-critical articles. Literature and art edition. Tashkent-1989.332-p.
3. O. Matjon "The Light of Faith". Selection. Publishing House of Literature and Art named after G. Gulom. Tashkent-1995.138-p.

4. O.Sharafiddinov "Loyalty to the truth". Literary-critical articles. Literature and art edition. Tashkent-1989.335-p

5. From the book "Trees and herbs" by O.Matjon, Tashkent-1984.

6. Шек, А. Б., Курбанов, Р. А., Абдуллаева, Г. Ж., Нагай, А. В., Абдуллаев, А. А., Ахмедова, Ш. С., ... \& Зияева, А. В. (2017). Особенности распределения полиморфизмов генов метаболизма и транспорта статинов в печени у больных ИБС этнических узбеков с непереносимостью симвастатина. Евразийский кардиологический журнал, (1).

7. Эшпулатов, А., Хошимов, Ш. У., Кан, Л. Э., Ахмедова, Ш. С., Аминов, С. А., Тригулова, Р. Х., ... \& Курбанов, Р. А. (2014). Особенности поражения коронарного русла у больных нестабильной стенокардией в зависимости от распределения полиморфизма гена аро СIII и характера дислипидемии. Евразийский кардиологический журнал, (3).

8. Хошимов, Ш. У., Ахмедова, Ш. С., Кан, Л. Э., Бекметова, Ф. М., \& Шек, А. Б. (2014). Влияние розувастатина и аторвастатина на уровень аполипопротеинов и маркеры воспаления у больных нестабильной стенокардией. Сибирское медицинское обозрение, (3 (87)). 